\title{
Вплив лазерного опромінення на накопичення біомаси та екзополісахаридів гриба Schizophyllum commune Fr.
}

\section{Катерина Решетник, Юрій Приседський}

Донецький національний університет імені Василя Стуса, Вінниця, Україна Адреса для листування: k.reshetnyk@donnu.edu.ua

Отримано: 28.05.20; прийнято до друку: 28.08.20; опубліковано: 02.09.20

Резюме. Досліджено вплив лазерного опромінення на накопичення біомаси та екзополісахаридів деяких штамів гриба S.commune. Для отримання інокулюму міцелій штамів S.c.-03, S.c.-01 та S.c.-02 гриба S.commune культивували на агаризованому глюкозо-пептонному середовищі (ГПСА). Під час дослідження впливу лазерного опромінення міцелію у поверхневій культурі використовували глюкозопептонне рідке живильне середовище (ГПС). Кількість екзополісахаридів визначали фенол-сірчаним методом. Найефективнішим за накопиченням біомаси та продуктивністю синтезу екзополісахаридів виявився штам S.c.-03 гриба S.commune - за дії лазерного опромінення міцелію червоним світлом (довжина хвилі 635 нм) біомаса міцелію зросла на 75,3\%, а кількість екзополісахаридів збільшилась на $70,7 \%$.

Ключові слова: Schizophyllum commune, шизофілан, поверхневе культивування, фотоактивація.

\section{Influence of laser irradiation on the accumulation of biomass and exopolysaccharides of the Schizophyllum commune Fr.}

\section{Kateryna Reshetnyk, Yuriy Prysedsky}

Vasyl' Stus Donetsk National University, Vinnytsia, Ukraine

Address for correspondence: k.reshetnyk@donnu.edu.ua

\begin{abstract}
The influence of laser irradiation on the accumulation of biomass and exopolysaccharides of some strains of S. commune has been studied. To obtain the inoculum of mycelium of strains S.c.-03, S.c.-01, and S.c.-02 of S.commune was cultured on agar glucose-peptone medium. In the study of the effect of laser irradiation of the mycelium in a surface culture used glucose-peptone liquid nutrient medium. The number of exopolysaccharides was determined by the phenol-sulfur method. The most efficient in terms of biomass accumulation and productivity of exopolysaccharide synthesis was the strain S.c.-03 of S.commune - under the action of laser irradiation of mycelium with red light (wavelength $635 \mathrm{~nm}$ ) mycelium biomass increased by $75.3 \%$ and the number of exopolysaccharides increased by $70 \%$.
\end{abstract}

Keywords: Schizophyllum commune, schizophilan, surface cultivation, photoactivation.

\section{ВСТУП}

Schizophyllum commune - один із найпоширеніших грибів у світі, його можна знайти на всіх континентах, за винятком Антарктиди [1]. S.commune - сапрофітний гриб, який викликає білу гниль деревини. Відомо близько 150 родів деревних рослин, які S.coтmипе використовує в якості субстрату [1]. Ця особливість робить його одним із перспективних біотехнологічних об'єктів, оскільки дозволяє S.commune колонізувати 
Lesia Ukrainka Eastern European National University Scientific Bulletin Series:

\section{Biological Sciences, 2020, 1 (389)}

величезне різноманіття лігноцелюлозних субстратів, розширюючи коло можливостей для отримання біотехнологічних продуктів, таких як біологічно активні речовини [2], ферменти [3], полісахариди [4], біоетанол [5] тощо, які можна отримати за допомогою цього гриба. Шизофілан також належить до полісахаридів, який отримують 3 культуральної рідини S.commune. 3 літератури відомо, що він має протипухлинні властивості і являє собою нейтральний $b-1,3-$-глюкан 3 молекулярною масою 450-1000 kD та залишається стабільний при температурі до $+145^{\circ} \mathrm{C}[6,7]$. Шизофілан відомий своєю здатністю підтримувати й посилювати клітинний імунітет та протипухлинні механізми [8], що робить його досить важливою речовиною, яку можна використовувати у виробництві лікарських препаратів. А отже, для розробки біотехнології отримання лікувально-профілактичних препаратів, основною діючою речовиною якого є екзополісахарид шизофілан, необхідно підібрати найпродуктивніші штами та визначити оптимальні умови культивування, які дозволятимуть інтенсифікувати процеси накопичення біомаси та полісахаридів гриба S.commune. 3 літературних джерел відомо, що для підвищення синтезу біомаси та екзополісахаридів застосовують різні модифікації живильних середовищ, різноманітне співвідношення компонентів середовища та його $\mathrm{pH}$. Згідно $з$ результатами досліджень Ліновицької та співавторів, відомо, що кращими для S.commune джерелами вуглецю $€$ глюкоза, гліцерин та маніт, джерелом азоту - пептон, триптофан та 3 неорганічних сполук - нітрат амонію. Також встановлено співвідношення азоту та вуглецю в середовищі - для максимального накопичення біомаси концентрація глюкози 30 г/л, нітрату амонію - 3 г/л, для максимальної кількості екзополісахаридів - 40 г/л та 4 г/л відповідно. Визначено, що для отримання максимальної кількості екзополісахаридів необхідно створювати вихідне значення $\mathrm{pH}$ середовища 8,0, а для більшого виходу біомаси - 5,4 [9]. У літературі відсутні відомості щодо вмісту екзополісахаридів у міцелії S.commune та накопичення біомаси за дії лазерного опромінення. Враховуючи вищезазначене, метою нашої роботи було вивчення впливу лазерного опромінення на накопичення біомаси та екзополісахаридів гриба S.commune.

\section{МАТЕРІАЛИ І МЕТОДИ}

Дослідження проводили на кафедрі ботаніки та екології Донецького національного університету імені Василя Стуса (ДонНУ імені Василя Стуса). Для дослідження були використані три штами гриба S.commune iз Колекції культур базидієвих грибів кафедри ботаніки та екології ДонНУ імені Василя Стуса, що входять до відділу Basidiomycota. Для отримання інокулюму міцелій штамів S.c.-03, S.c.-01 та S.c.-02 гриба S.commune культивували на агаризованому глюкозо-пептонному середовищі (ГПСА), г/л: глюкоза - 10,0; пептон 3,$0 ; \mathrm{KH}_{2} \mathrm{PO}_{4}-0,6 ; \mathrm{K}_{2} \mathrm{HPO}_{4}-0,4 ; \mathrm{MgSO}_{4} 7 \cdot \mathrm{H}_{2} \mathrm{O}-$ 0,$5 ; \mathrm{CaCl}_{2}-0,05 ; \mathrm{ZnSO}_{4} \cdot 7 \mathrm{H}_{2} \mathrm{O}-0,001$, дистильована вода - до 1 дм³ $^{3}$; агар-агар - 15 у чашках Петрі за температури $28 \pm 1^{\circ} \mathrm{C}$. Під час дослідження впливу лазерного опромінення міцелію у поверхневій культурі використовували глюкозо-пептонне рідке живильне середовище (ГПС) ), г/л: глюкоза - 10,0; пептон $-3,0 ; \mathrm{KH}_{2} \mathrm{PO}_{4}-0,6 ; \mathrm{K}_{2} \mathrm{HPO}_{4}-0,4 ; \mathrm{MgSO}_{4} 7 \cdot \mathrm{H}_{2} \mathrm{O}$ $-0,5 ; \mathrm{CaCl}_{2}-0,05 ; \mathrm{ZnSO}_{4} \cdot 7 \mathrm{H}_{2} \mathrm{O}-0,001$, дисти-

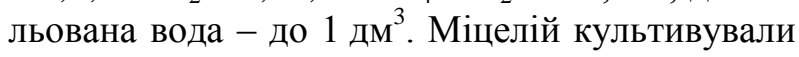
впродовж 7 діб за температури $28 \pm 1^{\circ} \mathrm{C}$ у термостаті в колбах Ерленмеєра об'ємом 250 мл, що містили 50 мл живильного середовища ГПС. Інокуляцію проводили дисками міцелію культур, що були вирощені на ГПСА. По п'ять дисків діаметром 5 мм вирізали стерильною сталевою трубкою на відстані 810 мм від краю активного росту колонії.

Для лазерного опромінення вегетативного міцелію використовували пристрій, який був сконструйований співробітниками кафедри ботаніки та екології ДонНУ імені Василя Стуса. Пристрій складається 3 8-гранної дзеркальної призми, що сприймає промінь LED лазерів: $\mathrm{BRP}-3010-5, \quad 3$ випромінюванням червоного спектра 3 довжиною хвилі 635 нм; ВВР-3010-5 3 випромінюванням синього спектра 3 довжиною хвилі 405 нм та BGP-3010-5 3 випромінюванням зеленого спектра 3 довжиною хвилі 532 нм (виробник лазерів ВОВ LASER Co., Китай) i відбиває його на транспортерну стрічку, на якій розміщується чашка Петрі $з$ міцелієм. Потужність кожного лазера становить 100 мВт. Пристрій має два електродвигуни, що відповідають за рух дзеркальної призми та транспортерної стрічки. Керування пристроєм здійснюється за допомогою панелі управління, оснащеної кнопками для регулювання часу опромінення та вибору необхідного лазера 3 відповідною довжиною хвилі світла (Рис. 1). 


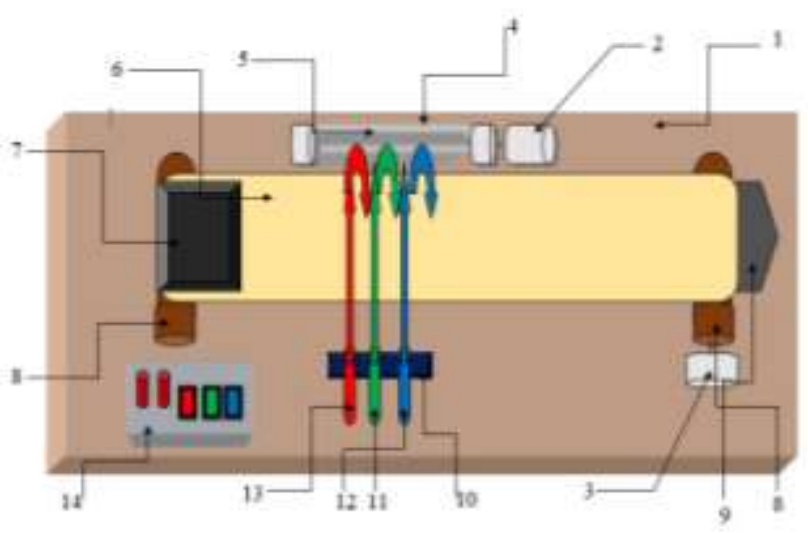

Рис. 1. Пристрій для опромінення міцелію монохроматичним світлом за допомогою LED лазерів.

1 - платформа для кріплення пристрою, 2 електродвигун, 1, 3 - електродвигун, 2, 4 захисна кришка для дзеркальної призми, 5 -

дзеркальна призма, 6-транспортерна стрічка, 7 - бункер для опромінених об' $є к т і в, ~ 8$ - валик, який рухає транспортерну стрічку, 9платформа для опромінених об'єктів, $10-$ штатив для кріплення LED лазерів, 11 LED лазер BGP-3010-5 з випромінюванням зеленого спектру з довжиною хвилі $532 \mathrm{mм}, 12$ -

LED лазер BBP-3010-5 з випромінюванням синього спектру з довжиною хвилі 405 нм, 13 LED лазер BRP-3010-5, з випромінюванням червоного спектру з довжиною хвилі $63 \mathrm{\mu м}, 14$ - панель управління.

Міцелій опромінювали в такий спосіб: чашка Петрі 3 міцелієм рухається на транспортерній стрічці під променем світла зі встановленою довжиною хвилі: 635, 405 та 532 нм, отримуючи необхідну енергію опромінення $\left(51,1\right.$ мДж/ $\left.\mathrm{cm}^{2}\right)$. Опромінення міцелію тривало $10 \mathrm{c}$. Потім за допомогою стерильної сталевої трубки з колонії міцелію вирізали міцеліальні диски діаметром 5 мм та здійснювали інокуцяцію на рідке живильне середовище (ГПС) відповідного складу. Для інокуляції контрольних чашок Петрі застосовували неопромінену культуру. Опромінення міцелію проводили в декількох варіантах (табл. 1).

Рівень накопичення біомаси визначали ваговим методом, висушуючи міцелій до постійної маси при температурі $(105 \pm 1){ }^{\circ} \mathrm{C}[10]$.

Для визначення концентрації екзополісахаридів спочатку проводили осадження 5 мл культуральної рідини 10 мл 96\% етанолу та відстоювання протягом доби при $(4 \pm 1)^{\circ} \mathrm{C}$, після чого осад відокремлювали центрифугуванням упродовж 25 хвилин при 67 тис. об/хв, розчиняли в 5 мл гарячої дистильованої води та відбирали 2 мл розчину, в якому визначали кількість екзополісахаридів фенол-сірчаним методом [11].

Усі досліди проводили у трикратній повторюваності. Для визначення вірогідності впливу лазерного опромінення на кількість біомаси та екзополісахаридів застосовували метод дисперсійного аналізу. Порівняння середніх значень здійснювали методом Даннета [12]. Обробку проводили за допомогою пакета статистичних програм, створених на кафедрі фізіології та біохімії рослин ДонНУ імені Василя Стуса [13].

\section{РЕЗУЛЬТАТИ ТА ОБГОВОРЕННЯ}

В результаті проведених досліджень 3 штамів базидієвого гриба S.commune на рідкому живильному середовищі (ГПС) встановлено оптимальний режим опромінення міцелію для накопичення екзополісахаридів та синтезу біомаси. Для лікарського гриба S.commune вперше отримано результати, які стверджують, що найефективнішим для цього виду макроміцета $\epsilon$ опромінення міцелію червоним світлом довжиною хвилі $635 \mathrm{Hм}$ (енергія опромінення $51,1 \quad$ мДж/ $\mathrm{cm}^{2}$ ).

\section{Схема опромінення міцелію гриба Schizophyllum commune}

Таблиия 1

\begin{tabular}{|c|c|c|c|c|}
\hline \multirow[b]{2}{*}{$\begin{array}{c}\text { Варіант } \\
\text { опромінення }\end{array}$} & \multicolumn{3}{|c|}{ Тривалість опромінення, с } & \multirow{2}{*}{$\begin{array}{c}\text { Енергія } \\
\text { опромінення, } \\
\text { мДж/см }{ }^{2}\end{array}$} \\
\hline & $\begin{array}{l}\text { Червоне світло } \\
\text { (довжина хвилі } \\
635 \text { нм) }\end{array}$ & $\begin{array}{c}\text { Синє світло } \\
\text { (довжина хвилі } \\
405 \text { нм) } \\
\end{array}$ & $\begin{array}{c}\text { Зелене світло } \\
\text { (довжина хвилі } \\
532 \text { нм) }\end{array}$ & \\
\hline 1 (контроль) & 0 & 0 & 0 & 0 \\
\hline 2 & 10 & 0 & 0 & 51,1 \\
\hline 3 & 0 & 10 & 0 & 51,1 \\
\hline 4 & 0 & 0 & 10 & 51,1 \\
\hline
\end{tabular}


Вплив лазерного опромінення на накопичення біомаси та екзополісахаридів гриба Schizophyllum commune Fr.

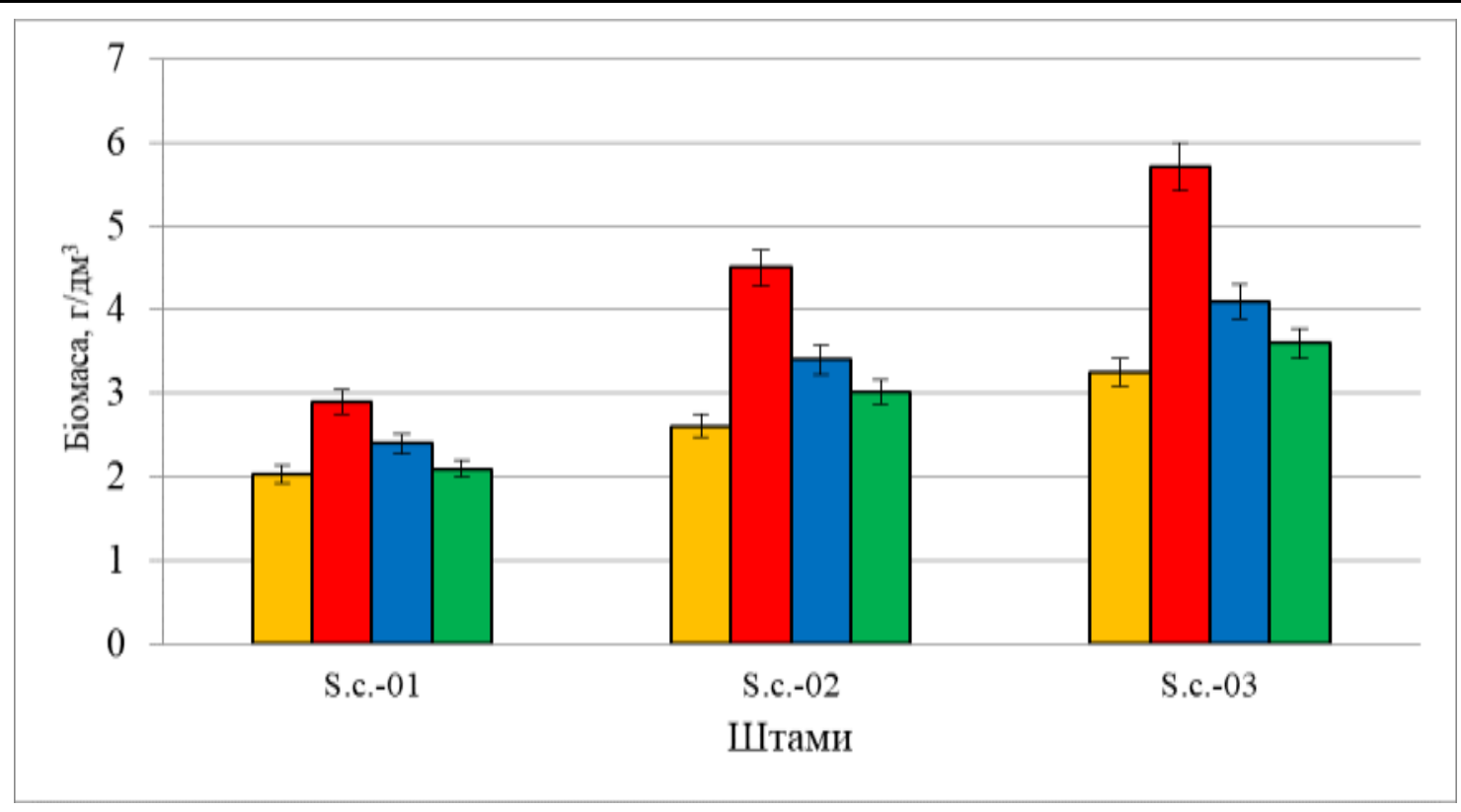

Рис. 2. Вплив лазерного опромінення на накопичення біомаси штамів Schizophyllum coттипе при культивуванні на глюкозо-пептонному середовищі. 7 доба культивування.

без опромінення, $\square 405$ нм; $\square 635$ нм; $\square 532$ нм.

За дії цього режиму опромінення найкраща реакція у відповідь на дію світла спостерігалась для штаму S.c.-03 - кількість біомаси зросла на 75,3\% відповідно до контролю. Для штамів S.c.-01 та S.c.-02 біомаса збільшилась на 72,4\% та на 48,2\% відповідно. Для S.commune ефективним також виявилося лазерне опромінення міцелію синім світлом довжиною хвилі $405 \mathrm{HM}$ (енергія опромінення 51,1

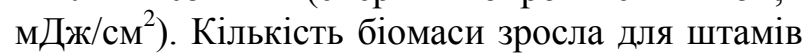
S.c.-03, S.c.-01 та S.c. -02 на 26,1\%, 18,2\% та на $43,2 \%$ відповідно. Опромінення зеленим світлом довжиною хвилі $532 \mathrm{Hм}$ (енергія опромінення 51,1 мДж/с $\mathrm{cm}^{2}$ ) викликало незначне зростання кількості біомаси міцелію для всіх досліджуваних штамів у межах від $3,4 \%$ до 16,5\% (рис. 2.).

Дослідження впливу лазерного опромінення на синтез екзополісахаридів гриба $S$. commune дало змогу встановити максимально ефективний режим фотоактивації міцелію. Отримані результати дають підставу вважати, що опромінення міцелію червоним світлом довжиною хвилі 635 нм (енергія опромінення 51,1 мДж/см $\left.{ }^{2}\right) \in$ найефективнішим. Для гриба S. commune протягом усього терміну культивування найвищий показник накопичення екзополісахаридів був зафіксований після опромінення міцелію червоним світлом довжиною хвилі 635 нм (енергія опромінення 51,1 мДж/см²). За дії цього режиму опромінення найкраща реакція у відповідь на дію світла спостерігалась для штаму S.c.-03 - кількість екзополісахаридів зросла на 70,7\% відповідно до контролю. Для штамів S.c.-02 та S.c.-01 концентрація екзополісахаридів збільшилась на $62,5 \%$ та на $66,7 \%$ відповідно. Лазерне опромінення синім світлом довжиною хвилі 405 нм (енергія

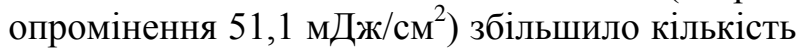
екзополісахаридів для всіх досліджуваних штамів у межах від $31,2 \%$ до $33,4 \%$. Опромінення міцелію зеленим світлом довжиною хвилі 532 нм (енергія опромінення 51,1 мДж/см²) викликало зростання кількості екзополісахаридів для всіх досліджуваних штамів від 11,7\% до 19,5 \% відповідно (рис. 3).

Отримані результати, порівняно 3 даними, наведеними в літературі, не високі. На нашу думку, це може пояснюватися складом живильних середовищ, використаних ученими, зокрема наявністю в них складних органічних компонентів, таких як меляса, кукурудзяний екстракт, дріжджовий екстракт тощо. Згідно 3 даними досліджень Smirnou зі співавторами [14], на середовищі з сахарозою та дріжджовим екстрактом отримували до $30 \quad \mathrm{r} /$ дм $^{3}$ міцеліальної біомаси та 3,5 г/дм ${ }^{3}$ екзополісахариду. За даними Ката зі співавторами [15], на оптимізованому середовищі з глюкозою (27 г/л) та дріжджовим екстрактом отримали 15,68 г/дм ${ }^{3}$ міцеліальної біомаси. В роботі Rau [16] наведено дані щодо синтезу 13 г/дм ${ }^{3}$ шизофілану. У роботі Ліновицької визначено кращі для S.commune джерела вуглецю для синтезу 


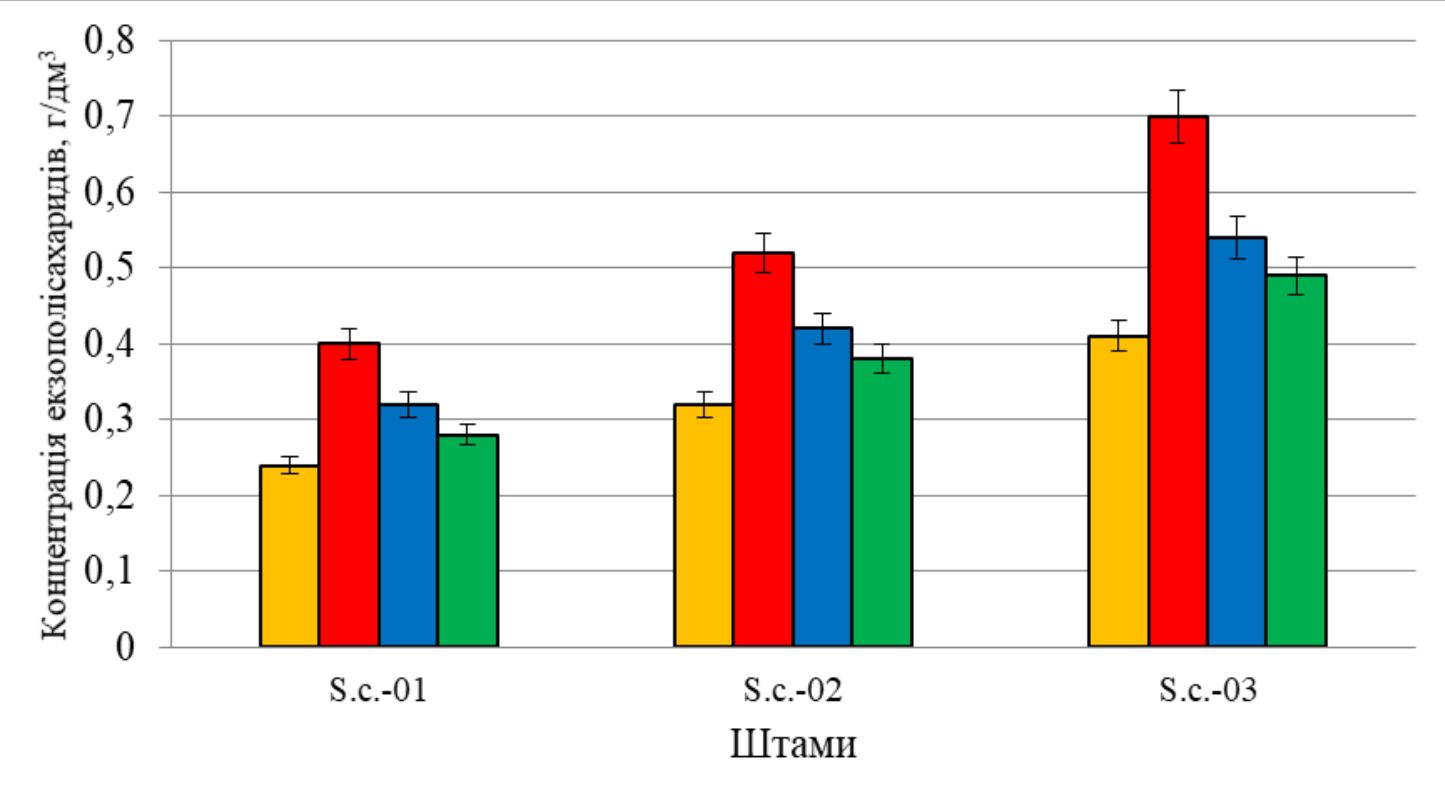

Рис. 3. Вплив лазерного опромінення на накопичення екзополісахаридів штамів Schizophyllum соттипе при культивуванні на глюкозо-пептонному середовищі. 7 доба культивування. без опромінення; $\square 405$ нм; $\square 635$ нм; $\square 32$ нм.

екзополісахаридів - глюкоза, гліцерин та маніт (1,54-1,63 г/дм залежно від штаму) та азоту пептон, триптофан та 3 неорганічних сполук нітрат амонію $\left(1,92-2,71\right.$ г/дм ${ }^{3}, 1,90-2,35$ г/дм ${ }^{3}$ та 1,04-1,71 г/дм ${ }^{3}$ відповідно). На комплексних середовищах найбільший рівень накопичення біомаси виявився на середовищах $3 \mathrm{KE}$ та мелясою - $(6,7 \pm 0,2)$ і $(8,8 \pm 0,3)$ г/дм ${ }^{3}$ відповідно. Визначення накопичення екзополісахаридів на комплексних поживних середовищах показало, що їх максимальна кількість виявляється на середовищі 3 кукурудзяним екстрактом $5,42 \pm 0,51 \Gamma^{2}$ дм $^{3}$ [9]. Проте нами вперше були отримані цікаві дані щодо впливу лазерного опромінення на синтез біомаси та полісахаридів гриба S.commune, згідно з якими спостерігається значне зростання кількості біомаси та синтезу екзополісахаридів за дії опромінення міцелію червоним світлом довжиною хвилі $635 \mathrm{Hм}$ та синім світлом довжиною хвилі 405 нм протягом $10 \mathrm{c}$. Отримані результати демонструють перспективність використання лазерного опромінення світлом у червоному і синьому діапазонах довжин хвиль для цілеспрямованої регуляції синтезу біомаси та екзополісахаридів. Водночас виявлено відмінності у фоточутливості гриба під час синтезу біомаси та екзополісахаридів залежно від довжини хвилі світла, що робить необхідним подальший пошук більш ефективних режимів фотостимуляції.
Уперше також наведено дані щодо накопичення біомаси міцелію та екзополісахаридів штамами S.commune при поверхневому культивуванні на рідкому живильному середовищі ГПС. Доведено ефективність використання лазерного опромінення міцелію гриба S.commune для отримання біомаси та продуктивності екзополісахаридів у всіх досліджених штамів S.commune. Найефективнішими за накопиченням біомаси та продуктивністю синтезу екзополісахаридів виявилися штами S.c.-03 та S.c.-02 гриба S.commune. Зокрема, за дії лазерного опромінення міцелію червоним світлом (довжина хвилі 635 нм) біомаса міцелію для штаму S.c.-03 зросла на 75,3\%, а кількість екзополісахаридів збільшилась на $70,7 \%$. Опромінення міцелію синім світлом (довжина хвилі 405 нм) збільшило кількість біомаси для штаму S.c.-02 на 43,2\%, а концентрація екзополісахаридів покращилась на $33,4 \%$.

\section{ЛIТЕРАТУРА}

1. Ohm, R.A.; de Jong, J.F.; Lugones, L.G.; Aerts, A.; Kothe, E.; Stajich, J.E.; Wösten, H.A. Genome sequence of the model mushroom Schizophyllum commune. Nature Biotechnology. 2010, 28(9), pp 957-963.

2. Wessels, J.G.H. Cell wall synthesis in apical hyphal growth. International Review of Cytology. 1986, 104, pp 37-79. 
3. Arboleda, Valencia J.W.; Valencia Jiménez A.; Gonçalves de Siqueira F.; Dussan Medina K.; Restrepo Franco G.M.; Filho E.X.F.; Grossi- de- Sa M.F. Holocellulase activity from Schizophyllum commune grown on bamboo: A comparison with different substrates. Current Microbiology. 2011, 63(6), pp 581587.

4. Singh, M.K.; Kumar, M.; Thakur, I.S. Proteomic characterization and schizophyllan production by Schizophyllum commune ISTL04 cultured on Leucaena leucocephala wood under submerged fermentation. Bioresource Technology. 2017, 236, pp 29-36.

5. Horisawa, S.; Ando, H.; Ariga, O.; Sakuma, Y. Direct ethanol production from cellulosic materials by consolidated biological processing using the wood rot fungus Schizophyllum commune. Bioresource Technology. 2015, 197, pp 37-41.

6. Ooi, V. A review of pharmacological activities of mushroom polysaccharides. Int. J. Med. Mushr. 1999, Vol. 3, pp 361-394.

7. Rice, P.J.; Lockhart, B.E.; Barker, L.A.; Adams, E.L.; Ensley, H.E.; Williams, D.L. Pharmacokinetics of fungal (1-3)- $\beta$-D-glucans following intravenous administration in rats. Int. Immunopharmacol. 2004, 4(9), pp 1209-1215.

8. Suzuki, T.; Tsuzuki, A.; Ohno, N.; Ohshima,Y.; Adachi, Y.; Yadomae, T. Synergistic action of beta-glucan and platelets on interleukin-8 production by human peripheral blood leukocytes. Biol Pharm Bull. 2002, 25(1), pp 140-144.
9. Ліновицька, В. М.; Бухало, А. С.; Швед, О. М.; Дуган, О. М. Створення біотехнології отримання екзополісахаридів на основі глибиного культивування вищого базидіоміцету Schizophyllum commune. Вісник Національного університету «Львівська політехніка», серія Хімія, технологія речовин та їх застосування. 2011, 700, с 161-172.

10. Дудка, И. А.; Вассер, С. П.; Элланская, И. А. и др. Методы экспериментальной микологии. Справочник. Наук. Думка: Київ, 1982; 561 с.

11. Варбанец, Л. Д.; Здоровенко, Г. М.; Книрель, Ю. А. Методы исследования эндотоксинов. Наук. Думка: Київ, 2006; 238 с.

12. Приседський, Ю. Г. Статистична обробка результатів біологічних експериментів. Кассиопея: Донецьк, 1999; 210 с.

13. Приседський, Ю. Г. Пакет програм для проведення статистичної обробки результатів біологічних експериментів. ДонНУ: Донецьк, 2005; $84 \mathrm{c}$.

14. Smirnou, D.; Krcmar, M.; Prochazkova, E. Chitin-Glucan complex production by Schizophyllum commune submerged cultivation. Polish J. Microbiol. 2011, 60, pp 223-228.

15. Kama, I.S.M.; Halim, K.H.A.; Rashid, N.M.N.; Mel, M. Optimization of media for mass production of Schizophyllum commune using response surface methodology (RSM). Malaysian International Conference on Trends in Bioprocess Engineering (MICOTriBE). 2012, pp 1-8.

16. Rau, U. Glucans secreted by fungi. Turkish Electronic Journal of Biotechnology. 2004, 2, pp 30-36. 